\title{
INCOME GENERATION IN INFORMAL SECTOR: A CASE STUDY OF THE STREET VENDORS OF KATHMANDU METROPOLITAN CITY \\ Dipak Bahadur Adhikari* \\ Email: dipakadhikari10@yahoo.com
}

\begin{abstract}
Street vending is important to income earn and poverty alleviation for some people of Nepal. The street trade provides employment and income generation for the rural poor in the urban areas. And not only rural poor are getting earning opportunities in the informal economy; this has been providing goods in cheaper price to urban poor. This paper analyzes the determinants of the street vender's income. It examines whether the income from vendor business of the people doing street business in Kathmandu metropolitan city increases with the rate of increase in investment, education and labor supply.
\end{abstract}

Keywords: street vendors, informal sector, income and employment, Kathmandu Metropolitan City

\section{INTRODUCTION}

The informal sector represents an important part of the economy and the labour market in many countries, especially in developing countries, plays a major role in employment creation, production, and income generation. The informal sector as defined in the resolution of the 15th International Conference of Labour Statisticians held in January 1993 refers to economic activities, that is, production and distribution of goods and services by the operating units of the households, which essentially differ from the formal sector in terms of technology, economies of scale, use of labourintensive processes, and virtual absence of well-maintained accounts. A variety of terms have been in vogue within the administrative setup and statistical systems of countries to describe enterprises satisfying one or more similar characteristics, such as "unregistered", "unorganized", micro-enterprises etc.

The informal sector represents a substantial portion of economic activity, especially in developing and transition countries. It is estimated that more than two thirds of total employment and more than one third of the total Gross Domestic Product (GDP) of the non-agricultural sector in Asia. In view of its estimated size the sector invites high policy interest in many parts of the world. Given their high potential for job creation and income generation in developing economies, the informal sector is gaining the attention of policymakers. Therefore, data on various characteristics and operations of

* Mr. Adhikari is Assistant Lecturer of Economics at Patan Multiple Campus, Tribhuvan University, Nepal 
these enterprises, output generated, employment provided, and constraints faced and their relationship with the formal sector are needed.

Unfortunately, due to their very nature, that is, their small size, invisibility, and high rates of entry and exits, informal sector enterprises do not enter the business registers or the list frames usually maintained by National Statistical Offices (NSOs). Thus, many enterprise surveys conducted by NSOs in developing countries usually target only enterprises beyond a threshold, generally measured in terms of size of employment, which are available in the official lists. As a result informal sector enterprises escape official data collection systems, and their contribution to GDP is often understated in the official national accounts data despite their significant contribution (Joshi, 2009).

Government of Nepal, Central Bureau of Statistics(GoN/CBS,2009) in its Labour Force Survey 2008 estimated that around 2142 thousand people aged 15 and over to be currently employed in the non-agricultural informal sector (70 percent of total non-agricultural employment) as compared to 1657 thousand in 1998/99 (73 percent of total non-agricultural employment). During the previous nine years the currently employed population in the non-agricultural informal sector grew by 29.3 percent. Distribution by sex show that males employed in the non-agricultural informal sector increased by 31.1 percent and for females by 26.1 percent. There were 759 thousand people aged 15 years and over who were currently employed in their own business with no employees in 1998/99 and this increased to 969 thousand in 2008 In total 77.5 percent of females and 66.0 percent of males have main jobs in the non-agricultural informal sector (GoN/CBS, 2009).

In the urban context, the informal sector refers to small enterprise operators selling food and goods or offering services and thereby involving the cash economy and market transactions. This so-called "urban informal sector" is more diverse than the rural one and includes a vast and heterogeneous variety of economic activities through which most urban families earn their livelihoods.

Street vending is one of the key manifestations of urban poverty especially in developing countries like Nepal. Now it has become growing sector of small-scale economic activity due to lack of alternative source of income. Street vending is a simple way of income generation by investing small capital. Thus poor people are interested in such activities. Most of the common goods such as local product, low cost jewellery, crafts, religious items, dolls, watches, socks, caps, toys, CDs, clothes, books, snacks, cooked foods, fruits, vegetables, radios etc. are available in the street.

In informal sector economic activities, street vendors are one of the most important parts. Street vending is a global phenomenon. In cities, towns, and villages throughout the world, millions of people earn their living wholly or partly by selling a wide range of goods on the streets, sidewalks, and other public spaces. With the advance of 
modern retailing fixed retail operations, department stores, and malls many expected that street vending would go away. Yet today, in most countries of the world, street vending persists and probably has expanded even where local regulations seek to ban or restrict it. It represents a feature except in societies where gender norms restrict women's mobility, women account for a major share of street vendors. However, with a few notable exceptions in mainly African countries, women traders are more likely than men traders to have the more risky work situations, by: operating from an open rather than a covered space; operating from the street rather than a cart or a stall; operating from an insecure or illegal space; trading in perishable goods; generating a lower volume of trade; working as commission agents or employees of other vendors; and not employing others to work for them. Consequently, women vendors also tend to earn less than men vendors.

In the case of a least developed country (LDC) like Nepal, the formal sector is very small to provide job opportunity to the large number of laborforce. Therefore obviously a large percent of the people is engaged in the informal economy for their livelihood and such segment is considerable in the urban areas. According to the Nepal Street Vendors Trade Union (NEST) representative, street vendors alone count about 30,000 in Kathmandu valley and more than 20,000 in Kathmandu metropolitan city.

As street vendors have been emerging as a major part in the informal sector activities in the urban areas of Nepal, the objective of this study is to identify the income impact of the street vendors through literacy level, labour supply, and investment.

\section{LITERATURE REVIEW}

The literature about informal sector has tremendously increased in different issues after ILO's Report of a Comprehensive Employment Mission to Kenya 1972. The mission's report acknowledges street trade as an important component of the informal sector but does emphasise that the visibility of street activities tends to lead to the neglect of other segments of the informal sector like manufacturing. The volume of informal sector activities in Nepal is very large (38.4\% of GDP). Some of the important literatures of informal sector study are presented here.

Unni and Rani (2000) provided evidence of the growing informalization of the labour force in South Asian Countries. A concept of the informal economy may be more useful to advocate these vulnerable groups of women. They have identified two broad components of the informal economy, that is, non-wage employment and wage employment. The first component of the informal economy non-wage employment in nonagricultural was increased during the eighties and nineties in Bangladesh and India, while it appeared to decline in Pakistan and Nepal. Within this first component they do find evidence of a large proportion of home-based workers and street vendors 
in some cities in India. Another large, but relatively declining component, was of unpaid family workers among women in all the countries. The second component of the informal economy, wage employment, is more difficult to clearly distinguish. They found an increasing proportion of casual employees in India and Bangladesh. Another segment of informal wage employment is constituted by home -workers or outworkers. Again evidence for the South Asian countries was not available. The trend towards increasing feminization of the workforce in the non-agricultural sector was observed in South Asia. The various components of the informal economy were found growing and an increasing participation of women in them are observed. The quality of the employment thus obtained is likely to be low. However, the chances are that this informal employment is what helps many households reduce the intensity of their poverty.

Reddy et al. (2001) analyzed the Urban Informal Sector in Fiji with the objectives of identifying types, nature, number and size of urban informal sector activities, examining the sector's contribution towards income generation, examining the impediments to the growth of urban informal sector activities, and identifying what the state could do to assist the urban informal sector. To fulfill these objectives primary data were used. The study was conducted using a structured questionnaire. Primary data was collected in Suva, Lautoka and Labasa. The study was limited to these three areas due to finance and time constraints. These three selected urban areas covered about 50\% of the country's urban population. A total of 150 respondents engaged in informal sector activities were interviewed. They were selected on the basis of a street-by-street survey; those who cooperated were interviewed.

This study shows that there has been a significant increase in the incomes and assets of those who are involved in the informal sector compared to their pre-informal sector days. The rise in the urban informal economy plays an important role in employment creation and labor absorption in the urban areas. Promotion of informal and small business activities have been as strategies in poverty alleviation and development in developing countries. It also shows that the average education level for those involved in the informal sector is no higher than primary school level. This study also shows that the growth of the urban informal sector provided goods and services at relatively low prices. Another significant finding is that 77 percent of the urban informal enterprises are carried out from a public place. The survey results showed that a half of the informal sector operators in urban areas actually resided in rural areas. This study also points out some of the key problems faced by the informal sector operators. Among the major problems are a lack of access to credit facilities, and the national and municipal laws and regulations. This study focused on urban informal sector and did not explain about rural informal sector which is most important in developing countries. 
Narayana et al., (2004) focused on informal sector to identify the changes that had occurred in their structure and composition in developing and transitional economies in recent year. In particular, informal sector has been making rapid strides not only it being the most important source of employment in many developing countries but also improving the conditions and circumstances of informal workers as the formal sectorboth private and public sectors- failed to generate sufficient employment opportunities. The importance of informal sector has been realised in view of its growing contribution to employment and income generation, especially in developing economies, despite the fact that it is being treated as an unimportant and low productive. The success of informal sector can only be realised if informal workers get the recognition of their economic contribution and potential as well as the removal of long-standing policy biases against them. The study concludes that, in the context of globalisation and economic reforms, the growth employment in the public sector is likely to slow down and, informal sector ought to play a major role in generating employment. The impact of informal sector is high on the economy in terms of employment and income creation to the large number of people both in rural and urban sectors. This study observed that informal sector is important, however, the success of programmes intended to promote informal sector, by and large, dependents on sector specific policy that would guide the development of the informal sector in the desired direction.

Kapunda and Mmolawa (2007) prepared a research on "The Role of Informal Sector and Self-employment in Poverty Alleviation in Botswana" with the main objectives of finding the contribution of the informal/ self-employment to total labor force, estimating the extent to which the informal activities generate further employment to others, estimating informal sector incomes at household and business levels, estimating the change in the income before and after owners joined the self-employment business. To fulfill these objectives primary and secondary data were used. The analysis was based on the nation-wide household income and expenditure survey especially the most recent one (2002/03). To complement and update the surveys, data from own survey in Gaborone, Lobatse and Ramotswa were used. The method used for the data analysis is statistical techniques and SPSS to compute frequencies and percentages as well as conduct cross tabulation.

This study showed that self-employment in Botswana was increasing in the past two decades or so. Furthermore, informal appeared important in poverty alleviation especially among women and the youth who tended to dominate the informal-self employment activities. The informal activities tend to generate further employment to either pay or unpaid workers who are employed by owners of such activities. On the average the study showed that the income welfare of these who joined the informal sector has improved. The study also urged to encourage the informal sector to be formal and contribute to government revenue for general development of Botswana. The survey data showed that almost 70 percent of those who joined informal sector did so in order to find a better income after staying unemployed for some time. 
Majority of households managing small-scale enterprises (mainly women) had only limited income despite their relatively large family size. Over 60 percent of owner of informal activities were single. About 40 percent had primary education or less. The majority (60 percent) had secondary education. The main reasons for joining the informal sector, the first reason given by 40 of the respondents was that they joined the informal sector because they were unemployed and had to take self-employment/ informal business as the last resort. 35 percent had a keen interest in self employment and wanted to their own bosses. Before that they were formally employed or students. 25 percent expressed that they needed a better income than what they used to have as well as to supplement their monthly salaries.The major recommendations related to informal sectors in the study were: that the government and non-governmental organizations should encourage the informal sector activities especially when they show good performance and expansion; special attention needed be given to the vulnerable groups such as women and the youth. The educated and those with entrepreneurial skills who would like to virtue into self-employment activities which create employment to others especially the poor, women and the youth, should also be supported by the relevant government and non-governmental agents.

Heinonen (2008) analyzed the hidden role of informal economy in Phnom Penh's development. The informal economy acts as a crucial part of the economy in Phnom Penh and it is extremely important for the city and its development, providing employment, income, and services for the majority of the citizens. Around 80 percent of the city's 400,000 slum dwellers earn their income from informal sources. The informal economy also attracted educated people when the formal sector has been unable to offer proper employment and income. Another side of the coin is the city's poor informal workers mostly living in slum settlements. These people do not have skills, capacities or capital to register their activities. And, as a matter of fact these people are disturbed by the formal arrangements such as regulations, fines and emotional stress that hinder their activities and possibilities to earn decent income. The study remarked that the informal economy is not regulated, which has created many obstacles for the city's development. To achieve sustainable development of the city's economy and services, the municipality need to co-operate with the informal sector, develop services to support, monitor and regulate informal activities, and lighten the registration process. To be able to create an effective legal framework for informal activities, more information about the sector and its needs, obstacles, and behaviors is needed.

Olofin and Folawewo (2009) examined the structure and diversity of informal sector activities to evaluate the impact of 'aid for trade' programmes on informal sector activities, to estimate the extent to which trade assistance programmes have enabled the LDCs in the region to grow to trade. Some major findings of the study deserving further evidence particularly from the context of developing countries were that there have been some positive effect of trade on manufacturing sector employment but the 
effect of trade on employment depended on the prevailing job search behavior and the nature of the labour market in an economy. The trade liberalization produced both positive and negative effects on employment in terms of job creation and job destruction; that in the long run trade is expected to increase inequality between capital and labour or between skilled and unskilled labour in developed countries, while the gap is expected to narrow in developing countries; the effect of trade on employment in the short run depended on country specific factors, however, in the long run the efficiency gains caused by trade liberalization are expected to lead to positive employment effects, either in terms of quantity or quality of job creation or a combination of both.

Otoo et al. (2009) analyzed women Entrepreneurship in West Africa in the Cowpea Street Food Sector in Niger and Ghana. The main objectives of the study were: to determine the importance of the cowpea-based street food sector in Niger and Ghana, to evaluate internal and external factors that drive the success of cowpeabased street food enterprises, to conduct a cross-country comparison to determine the impact of religious, cultural, income and geographic differences on the success of women entrepreneurs selling cowpea-based street foods. This paper was based on both primary and secondary data collected via in-person interviews with 114 and 122 women street food entrepreneurs in the Niamey of Niger, Kumasi of Ghana in 2009. Additional secondary data on minimum wages and population of selected zones were obtained from government and research agencies. OLS regressions were further used to determine entrepreneurial success. The study observed that women entrepreneurship in the informal sector, such as street food vending is important for economic development and poverty alleviation in West Africa. The street food sector provides employment for women and inexpensive and nutritious food for the urban poor. In this paper, the researchers determined the importance of the cowpea street food sector, evaluated the determinants of successful enterprises and ascertained the impact of economic, cultural and religious and geographic differentials between enterprises in Niamey and Kumasi.

The main findings of this study were: women entrepreneurs engaged in the cowpea street food sector were earning income significantly higher than the minimum legal wage in Niamey and Kumasi. These vendors are micro entrepreneurs rather than dependent workers, providing employment not only for them but also for other people. Incomes earned from these entrepreneurial activities contributed directly to health, education and other needs of their families. Higher educational levels are not associated with more successful enterprises which are contrary to much of the business literature. The reasoning for this phenomenon is that these individuals may be involved in street food vending as a temporary activity while they search for better employment opportunities and have no incentive to invest and expand their businesses. Family support is central to the operation of most street food enterprises, particularly where religious beliefs dictate the manner in which women entrepreneurs conduct 
their business. Cross-country comparisons revealed that enterprises in Kumasi are larger and more successful (earning higher incomes) than those in Niamey. Religious beliefs influence business success in Kumasi where seclusion rules result in "strictly observant Muslims" entrepreneurs earning less income than Christian entrepreneurs. The study concluded that women street food enterprises are important avenues for employment and income generation. Enterprise development strategies geared at poverty alleviation in West Africa should include proactive measures that alleviate market barriers specific to informal women entrepreneurship such as street food vending.

Timalsina (2011) concentrated on the street vending activities of Kathmandu Metropolitan City in order to examine the livelihood opportunity to poor or challenges for urban governance in the urban informal economy. The main objectives of the study were: to show the income and employment opportunities of street vendors in Kathmandu Metropolitan City, to analyse the livelihood opportunity of urban poor. This study was based on both primary and secondary data. The main findings of this study were: rural migrants, having low level of education and skills, are forced to involve in the informal economy for their scanty livelihood. Street vending activities has become an easy access to those migrants' vendors in Kathmandu. Those vendors see street vending as an opportunity for work and employment in the urban areas and take street vending as an earning opportunity and an opportunity to provide livelihoods to dependent family members. Poor, better off people and some educated fellows have been engaged on the street of Kathmandu for making a living. Not only rural poor are getting livelihood opportunities in informal economy, vendors are providing goods in cheaper price to another section of urban poor that otherwise would be impossible to provide by the urban authorities or by the urban governance system. Thus street vending has become opportunity of marketing space to most of the urban poor in Kathmandu Metropolitan City.

\section{RESEASRCH METHODOLOGY}

The present study aims to investigate the factors affecting the incomes of the street vendors in the Kathmandu Metropolitan city. Researchers have used different methods to measure the informal sector activities. However no single method can capture all the informal sector activities simultaneously. In the case of Nepal, Labour Force Survey has used household survey method to collect the information of the informal sector.

In social science research, field work is the central and important method for collecting the primary information. Secondary information also plays an important role while analyzing and giving inference of some empirical knowledge. So, this study is based on both primary and secondary data. Data collection methods are primarily determined by the kinds of questions to be answered, as well as the type of research to be conducted, and also the nature of the research itself. As far the primary data is concerned, structured questionnaire was used to collect data of street vendors 
in Kathmandu metropolitan city. The activities of street vendors of Kathmandu metropolitan city area has been clustered in few locations and for the study 170 sample size has been taken on the basis of their activities. The secondary information is collected from the office record, books, and bulletins, periodic and annual reports of different government agencies. The website of the concerned government agencies has been used to collect the secondary data.

\section{Sampling Design}

The present study on the street vendors of Kathmandu is focused into two areas namely Ratna park area and New Bus park area. The size of occupations for interview was determined by observation method following a pilot survey. Most of the respondents are of semi-mobile nature, some are fixed and some possess mobile activities. The size of each type of occupation was kept in proportion to their universe size as observed in the pilot survey, which has been conducted at locations for interviews and selected randomly on the basis of occupation. The interview of most of the respondents, who were in semi-mobile and mobile activities, has been taken at working place.

\section{Size of Sample}

According to the Nepal Street Vendors Trade Union (NEST) representative, street vendors alone count about 1700 population size in these study areas. Many street vending activities are subject to seasonal effect and change over time. The information was taken within one month period from February 1, 2011 to March 1, 2011. The questionnaire included most of the activities which were done within one year. Table 1 reveals the concentration of street vending in the selected area of Kathmandu.

Table 1: Street Vendors' Concentration in Kathmandu Municipality

\begin{tabular}{|l|l|}
\hline Area & Number \\
\hline Ratnpark- area & 1,000 \\
\hline New Buspark area & 700 \\
\hline Total & 1700 \\
\hline
\end{tabular}

Source: Nepal Street Vendors Trade Union

Our sample size is $10 \%$ of total population, that is, 170 out of 1700 . From each location $10 \%$ of the street vendors were selected randomly, that is, 100 vendors from Ratnparkarea and 70 vendors from New Buspark area were included in the sample. Then they were interviewed individually by the researcher.

\section{Model Specification}

The general functional form of the factors affecting the income of the street vendors of the Kathmandu Metropolitan city is expressed as: 
where, $\mathrm{Y}=$ income, INV = investment in this sector; $\mathrm{LS}=$ supply of labour in this sector, $\mathrm{EL}=$ education level of workers.

In this model, income represents the monthly income of respondent. Investment means the money spent in the starting phase of business and supply of labour indicates the total members of a family involved in this sector. Education level of the respondent also plays a vital role in generating their income. Illiterate, under SLC and SLC or above have been used to represent the level of education of the individual operating the street vending.

EMPIRICAL RESULTS AND DISCUSSION Table 2 shows that larger numbers of uneducated respondents were involved in this field but the average monthly income and investment were found less as compared to that of the literate. Table shows that higher the level of education higher the level of income. Highly educated respondents were found to have earned around double than illiterate respondents in this activity. It means that educated respondents have many ideas about business; they know how to deal with their customers as well as which items is the best for sale to generating income. There was a small difference in average monthly working days and average working hour per day among different education levels.

Table 2: Basic Information of Education level with Income, Investment, Education Level, Average Monthly Working Days, and Average Working Hour per Day

\begin{tabular}{|l|c|c|c|c|c|}
\hline Education level & $\begin{array}{c}\text { Total } \\
\text { respondents }\end{array}$ & $\begin{array}{c}\text { Average } \\
\text { monthly } \\
\text { income }\end{array}$ & $\begin{array}{c}\text { Average } \\
\text { initial } \\
\text { investment }\end{array}$ & $\begin{array}{c}\text { Average } \\
\text { monthly } \\
\text { working days }\end{array}$ & $\begin{array}{c}\text { Average } \\
\text { working } \\
\text { hour per day }\end{array}$ \\
\hline Illiterate & 70 & 13,471 & 23,878 & 28.2 & 8 \\
\hline Under S.L.C. & 63 & 14,801 & 42,595 & 27.9 & 8.1 \\
\hline S.L.C. or above & 37 & 21,710 & 69,662 & 28.1 & 8.3 \\
\hline
\end{tabular}

Source: Field Survey, 2011.

\section{Investment}

Due to the lack of opportunities in other sectors, street vending is a good investment opportunity to invest a little amount, which they either invest themselves or take as loans from the microfinance companies. Investment is positively correlated with income, which implies that higher the level of investment leads to higher the level of income.

Investments in street vending start from as low as Rs.1000 to over Rs.1 million. When a vendor decides on the goods to trade, they have to make a decision based on the 
ability to invest. The types of good traded in the streets are of varied investment levels. Since the probability of getting goods for credit during the startup phase is very low, sufficient investment in goods is a crucial part to start a vending business. However, 38 per cent vendors invest less than NRs.10, 000 during startups. And around more than 80 per cent venders invest less than NRs.50, 000 in initial phase. That means only around 20 percent vendors make large investments in purchasing the prime spots or on differentiated quality goods.

\section{Occupational Effects of the Street Vendors}

The types of occupation of the respondents in terms of income, investment and other variables in this sector have been shown in Table 3. The largest size among the occupation types was clothes but its size of income was found the second largest after cooked food. Among the occupation types, cooked food earned higher income than others; however clothes items need more investment than the cooked food items. There was the same relation between vegetable and cosmetic, vegetable vendors earned more with little investment than cosmetics but just opposite cosmetic venders needed more investment to earn less income than vegetables. Table 3 shows that the ratio between income and investment was highly significant in service sector than others. After that the ratio between income and investment was highly significant in vegetable sector. In types of occupation, education level cannot play a significant role.

Table 3: Occupation- wise Income with Investment, Education Level, Average Monthly Working Days, and Average Working Hour per Day

\begin{tabular}{|l|c|c|c|c|l|c|}
\hline $\begin{array}{l}\text { Types of } \\
\text { occupation }\end{array}$ & $\begin{array}{l}\text { Total } \\
\text { respondents }\end{array}$ & $\begin{array}{l}\text { Average } \\
\text { monthly } \\
\text { income }\end{array}$ & $\begin{array}{l}\text { Average } \\
\text { initial } \\
\text { investment }\end{array}$ & $\begin{array}{l}\text { Average } \\
\text { schooling } \\
\text { year }\end{array}$ & $\begin{array}{l}\text { Average } \\
\text { monthly } \\
\text { working } \\
\text { days }\end{array}$ & $\begin{array}{l}\text { Average } \\
\text { working } \\
\text { hour per } \\
\text { day }\end{array}$ \\
\hline Cloths/sh & 86 & 15,081 & 55,389 & 5.3 & 28.4 & 7.2 \\
\hline $\begin{array}{l}\text { Vegetable } \\
\text { and Fruits }\end{array}$ & 38 & 14,473 & 13,328 & 2.6 & 26.4 & 8.9 \\
\hline Food (co.) & 21 & 25,919 & 42,142 & 5.0 & 29.0 & 7.9 \\
\hline Cosmetics & 19 & 12,078 & 37,894 & 7.2 & 28.3 & 9.4 \\
\hline Services & 6 & 9,666 & 9,583 & 2.3 & 29.7 & 10.2 \\
\hline
\end{tabular}

Source: Field Survey, 2011.

The multiple regression equation was estimated in the STATA software. The empirical results are given in Table 4. Dependent vitiable is income of the street vendors. 
Table 4: Determinants of Street Vendors' Income in Kathmandu Metropolitan City

\begin{tabular}{|l|c|}
\hline Variables & Coefficients \\
\hline \multirow{2}{*}{ INV } & $0.0483^{* * *}$ \\
& -0.011 \\
\hline \multirow{2}{*}{ LS } & $4,876^{* * *}$ \\
& -902.1 \\
\hline \multirow{2}{*}{ EL1 } & $-5,110^{* * *}$ \\
& $-1,696$ \\
\hline \multirow{2}{*}{ EL2 } & $-4,188^{* *}$ \\
& $-1,691$ \\
\hline \multirow{2}{*}{ Constant } & $10,044^{* * *}$ \\
& $-1,947$ \\
\hline R-squared & 0.39 \\
\hline F-statistics & 26.16 \\
\hline Number of observations & 170 \\
\hline Note: Standard errors in parentheses. & $* * * \mathrm{p}<0.01,{ }^{* *} \mathrm{p}<0.05,{ }^{*} \mathrm{p}<0.1$
\end{tabular}

The result shows that the effect of the selected variables on the income of the street vendors is significant. The result reveals that number of employed has highly significant impact in bringing change in income earned by person. The positive sign of coefficient conforms that increase in worker brings increase in their income. The coefficient indicates that increase in workers by one increase the incomes of the street vendors by around Rs.4, 876 per month.

The result given in Table 4 reveals that education is another important variable affecting the incomes of street vending business. This variable is categorized into three levels illiterate, under SLC, and SLC or above. Third level is dropped from the analysis to make it the reference group. The education variables are found significant but have a negative sign. The coefficient of EL1 indicates that the income of the illiterate respondents is Rs. 5,110 less than that of the respondents having SLC or above. Similarly, the coefficient of EL2 indicates that the income of the below SLC respondents is Rs. 4,188 per month less than that of the respondents having SLC or above. This shows that business performance of educated people is higher than that of non-educated people.

Investment is another important variables, it bring significant positive effect in street venders income. The coefficient of the investment variable is positive which conforms that increase in investment brings increase in income of the venders. The coefficient indicates that Rs. 1 increase in investment brings near about Rs. 0.0483 increase in income. The estimated model is capable of explaining about 40 percent variation in income as indicated the value of $\mathrm{R}^{2}$. 


\section{CONCLUSION}

Informal sector came into use in the early 1970s when the International Labour Organization (ILO) first coined the term informal sector. Street vending sector is an important sector that is providing employment and income to the rural poor people in urban sector. Currently there are more than 30,000 street vendors in Kathmandu valley and more than 20,000 in Kathmandu metropolitan city that has provided employment and livelihood for poor people. In this study all the variables chosen to explain the incomes of the street vendors of Kathmandu Metropolitan City are highly significant. There is positive relationship between dependent and independent variables. Street vender's income increases with the increase in investment, education and labor supply.

Generally, street vending requires less investment and the income from that investment is satisfactory for at least sustaining a family in the city. This study found that even though level of income and profit in this sector's activities are lower than from other business, more people are involved into the vending business. It is because of the lack of employment opportunities in other sectors in the economy. The widely involved population in the street vending business is the rural population. The rural population by large is involved in agriculture. As each individual possesses a small area of land to cultivate, it becomes difficult to sustain the family as it grows. Therefore large number population is involved into trade in the street to earn that livelihood.

Street vending business is one form of entrepreneurship. But because the contribution of this industry in the GDP of the national economy is not included and taxes are not paid to the government, it is an informal form of entrepreneurship. If street vending can be brought under the legality, and if the taxes can be collected it will groom as one of the best forms of entrepreneurship that make sizeable contribution to the economy.

\section{Acknowledgements}

The author is highly indebted to Professor Dr. Nav R Kanel, Central Department of Economics, TU, Associate Professor Madhav Prasad Dahal, Department of Economics Patan Multiple Campus and executive editor of EJDI, and Dr. Chakra Bahadur Khadka, Department of Economics Patan Multiple Campus for their contribution in improving the paper.

\section{References}

Government of Nepal, Central Bureau of Statistics (2009). Nepal labour force survey 2008 statistical report. Thapathali, Kathmandu: Author.

Heinonen, U. (2008). The hidden role of informal economy: is informal economy insignificant for Phnom Penh's development? In M. Kummu, M. Keskinen \& O. Varis (Eds.), Modern myths of the Mekong, (pp. 123-132). Helsinki, Finland: Water and development publications - Helsinki University of technology. Retrieved on February 10, 2012 from 
http://www.water.tkk.

Joshi, K., Hasan, R., \& Amoranto, G. (2009). Surveys of informal sector enterprises- some measurement issues. ADB economics working paper series No. 183. Asian Development Bank

Kapunda, S.M., \& Mmolawa, B.D. (2007). The role of informal sector and self-employment if poverty alleviation on Botswana. Gaborone, Botswana: Department of Economics, University of Botswana P/Bag 0022. Retrieved on January 10, 2012 from http://www. bidpa.bw.

Narayana, N., Kaino, D.K., \& Sekwati, L. (2004). Informal sector experiences of developing and transitional economies. Gaborone, Botswana: Department of Economics, University of Botswana, Private Bag 0022. Retrieved February 10, 2012 from http://www.bidpa.bw.

Olofin, S.O. \& Folawewo, A.O. (2009). Trade reforms, informal sector activity and employment. A research discussion paper prepared for the joint WTO-ILO workshop on global trade and employment, 31 August-1 September, 2009, Geneva, Switzerland.

Otoo, M., Fulton, J., Ibro, G., \& Lowenberg-DeBoer, J. (2009). Women entrepreneurship in West Africa: the Cowpea street food sector in Niger and Ghana. A research project supported by the Borlaug LEAP Fellowship Program and the Purdue Improved Cowpea Storage (PICS) program. Retrieved April 29, 2012 from http://whitman.syr.edu.

Reddy, M., Naidu, V., \& Mohanty, M. (2001). The urban informal sector in Fiji: Results from a survey. Fijian Studies, 1(1), 127-154. Retrieved March 10, 2012 from http://www. openwebsolutions.net.

Timalsina, K. P. (2011). An urban informal economy: Livelihood opportunity to poor or challenges for urban governance, study of street vending activities of Kathmandu metropolitan city. International Journal of Politics and Good Governance, 2(2.2), Quarter II, $1-13$

Unni, J., \& Rani, U. (2000). Women in informal employment work: Informalization and flexibilisation: new forms of women's paid work. The International Association for Feminist Economics Conference. Istanbul, Turkey: Bogazici University. Retrieved on April 10, 2012 from http://previous.wiego.org. 